DobromiŁa GoŁębiak

\title{
Proces Franza Kafki jako metafora, czyli studenckie próby adaptacji powieści
}

\begin{abstract}
Prawo dane zostało człowiekowi nie po to, aby mógł kierować się nim i słuchać, ale po to, by ujawnić i pokazać mu jego bezsilność i bezradność [...] prawo wini, przeraża i osądza ${ }^{1}$.
\end{abstract}

Reżyser dokonujący adaptacji powieści staje przed nie lada wyzwaniem. $Z$ jednej strony jest czytelnikiem oryginału i interpretatorem, który - jak każdy obcujący z dziełem sztuki - ma prawo do własnego twórczego odczytania, z drugiej zaś musi liczyć się z gustami publiczności. Twórcze zmagania i towarzyszący mu niepokój są jeszcze trudniejsze w przypadku, gdy młody reżyser sięga po dzieło powszechnie znane i doceniane. W takiej sytuacji znaleźli się twórcy analizowanych przeze mnie filmów. Przedmiotem mojej uwagi nie są bowiem filmy znane szerokiej publiczności, lecz adaptacje Procesu Franza Kafki dokonane przez studentów reżyserii Wydziału Radia i Telewizji Uniwersytetu Śląskiego. Uważam, że warto zainteresować się owymi etiudami studenckimi z co najmniej dwóch powodów: z uwagi na niezwykły materiał literacki i problemy związane z jego adaptacją, a także ze względu na niebanalny i niekonwencjonalny sposób odczytania Procesu, który stał się udziałem młodych twórców.

Realizacja adaptacji jest warunkiem zaliczenia drugiego roku reżyserii na Uniwersytecie Śląskim. Studenci nie wybierają samodzielnie literackiego pierwowzoru. Decyzja o przedmiocie adaptacji jest przywilejem wykładowcy sprawującego artystyczną pieczę nad pracami młodych twórców. Opiekunem reżyserów analizowanych przeze mnie filmów jest Filip Bajon, który ma na swoim koncie kilka adaptacji znanych szerokiej

1 Lew Szestow, Ateny i Jerozolima, tłum. Cezary Wodziński, Wyd. Literackie, Kraków 1993, s. 228. 
publiczności. Warto wspomnieć chociażby o Przedwiośniu (2001) według powieści Stefana Żeromskiego czy też Ślubach panieńskich (2010) opartych na sztuce Aleksandra Fredry. Jest to zatem reżyser w pełni świadomy problemów, jakich nastręcza adaptacja dzieła literackiego. Sądzę, że nie bez powodu wybrał Proces jako materiał do zaliczeniowej etiudy.

Rozważania na temat adaptacji Procesu warto poprzedzić refleksją na temat struktury powieści i problematyki podejmowanej przez Franza Kafkę. Zdaniem Alberta Camusa „cała sztuka Kafki polega na zmuszeniu czytelnika do ponownej lektury. Jego rozwiązania, czy brak rozwiązań, sugerują wyjaśnienia, które nie całkiem są jasne i żądają przeczytania nowego i pod kątem, który je uzasadni"'2. W istocie, dzieła Kafki - jego powieści, opowiadania, dzienniki - są przedmiotem rozlicznych lektur i interpretacji. Reżyserzy, podejmujący trud adaptacji Procesu muszą mieć zatem świadomość, że ich widzowie znają literacki oryginał i będę oczekiwać nie tylko streszczenia powieści, lecz także dialogu z nią. Odbiorcy filmu będą zmierzali

ku zbudowaniu jedności, która nie jest już dłużej tylko książką ani wyłącznie filmem w danym momencie oglądanym. Percepcja zostaje ukierunkowana na stworzenie syntezy, która rodzi się tylko w umyśle widza i nigdzie poza nim nie istnieje. Końcowym wytworem oglądanego filmu będącego adaptacją książki jest więc dzieło wirtualne ${ }^{3}$.

W procesie adaptacji, rozumianej jako twórcza lektura i interpretacja, reżyser staje się niejako egzegetą objaśniającym czy też koncentrującym uwagę widza na wybranych aspektach powieści.

Proces nastręcza adaptatorowi wielu trudności. Sposób prowadzenia narracji bardziej przypomina filozoficzne traktaty egzystencjalistów aniżeli klasyczną powieść ${ }^{4}$. Fabuła Procesu jest niezwykle trudna do zaadaptowania na potrzeby scenariusza filmowego. Zawiązanie i rozwiązanie akcji wydaje się następować w tym samym momencie, równocześnie, już na samym początku historii Józefa K. Dowiadujemy się wówczas, że zostaje oskarżony, jego dalsze perypetie utwierdzają nas w przekonaniu, że ów absurdalny akt oskarżenia nie zostanie uchylony. Z punktu widzenia zdrowego rozsądku sytuacja Józefa pozbawiona jest jakiegokol-

2 Albert Camus, Nadzieja i absurd w dziele Franza Kafki, tłum. Joanna Guze, [w:] tenże, Eseje, tłum. Joanna Guze, PIW, Warszawa 1971, s. 187.

3 Alicja Helman, Twórcza zdrada. Filmowe adaptacje literatury, Ars Nova, Poznań 1998, s. 17.

4 Michał Głowiński, Powieść, [w:] Słownik terminów literackich, red. Janusz Sławiński, Zakład Narodowy im. Ossolińskich - Wydawnictwo, Wrocław 2002, s. 416. 
wiek sensu i logiki. Józef nie ma możliwości wydostania się ze swojego absurdalnego świata. Poznawani przez nas bohaterowie i sugerowane przez nich rozwiązania sytuacji utwierdzają nas w przekonaniu, że znalazł się w sytuacji bez wyjścia. Niezależnie od tego, czy towarzyszymy Józefowi w jego pokoju, w dusznych sądowych korytarzach, czy też w katedrze, tkwimy w tej samej pułapce. Nie ogranicza nas bowiem ani czas, ani przestrzeń, lecz absurd ludzkiego losu. Jesteśmy, wraz z Józefem K., skazani na bezowocne poszukiwania. Od samego początku znamy jednak ich rezultat i wiemy, że nie zdołamy uciec z irracjonalnego świata, w który zostaliśmy wrzuceni. Wyrok zapada nagle, i samo postępowanie przechodzi stopniowo w wyrok ${ }^{5}$.

Biorac pod uwagę skomplikowaną i wielowymiarową fabułę, można podać w wątpliwość, czy udana adaptacja Procesu jest w ogóle możliwa. W tym miejscu warto powołać się na rozważania Alicji Helman i przytaczanych przez nią teoretyków. Dobry film nie musi być wcale wierną adaptacją, ta może w sposób daleki odbiegać od literackiego oryginału'. Realizatorzy filmów będących przedmiotem moich analiz traktują Proces jako punkt wyjścia do swoich poszukiwań. Nie jest to jednak zarzut wobec reżyserów. Adaptować nie oznacza bowiem nic innego, jak przerabiać, odczytywać na nowo, umieszczać w innym kontekście kulturowym i społecznym. Od napisania Procesu do powstania omawianych etiud upłynęło prawie sto lat. Zmienił się nie tylko język literatury, lecz przede wszystkim kina. Dlatego też reżyserzy nie starają się dokonać przekładu, ich praca jest świadectwem własnego odczytania dzieła, często poprzez pryzmat współczesnych doświadczeń i teorii.

Przedmiotem moich rozważań będą trzy etiudy filmowe. Dwie z nich, Muka! w reżyserii Kordiana Kądzieli oraz Defekt Małgorzaty Suwały, stanowią rodzaj komentarza do Procesu, starają się dochować wierności oryginałowi, a jednocześnie selekcjonują fragmenty powieści i analizują wybrane jej elementy. Inaczej rzecz ma się w przypadku Poczekalni w reżyserii Michała Wawrzeckiego, gdzie fabuła powieści została potraktowana jako inspiracja do stworzenia nowego dzieła, pozostającego jednakże wiernym oryginałowi w kwestii podejmowanych problemów filozoficznych. Reżyserzy wiedzą, że język literatury nie jest przekładalny na język filmu. Polemizują z autorem Procesu, a od kompetentnej widowni wymagają nie tylko znajomości dzieł Kafki, lecz także otwartości na nowe interpretacje.

\footnotetext{
5 Franz Kafka, Proces, tłum. Bruno Schulz, Wyd. Inicjał, Łódź 1994, s. 140.

6 Alicja Helman, dz. cyt.
} 


\section{Muka!, czyli piętno}

Muka! w reżyserii Kordiana Kądzieli, znana widzom 37. Festiwalu Polskich Filmów Fabularnych w Gdyni, to adaptacja, która oddaje rysy literackiego oryginału w sposób dość swobodny. Akcja filmu rozgrywa się $\mathrm{w}$ czasach współczesnych. Józef nie jest urzędnikiem, lecz nocnym stróżem. Dla autora filmu, podobnie jak dla Franza Kafki, profesja Józefa nie ma większego znaczenia. Jest on everymanem, którego los to parabola ludzkiej egzystencji. Film Kordiana Kądzieli nie dokonuje prostej transpozycji fabuły Procesu na język filmu. Akcja Muki! rozpoczyna się o poranku. Główny bohater, zamknięty w ciasnej przyczepie campingowej, czeka na swojego zmiennika Zygę, oglądając telewizyjny teleturniej. Widzowie domyślają się, że bohater jest kimś w rodzaju stróża, choć jego pracę można by scharakteryzować jako bezsensowne czekanie.

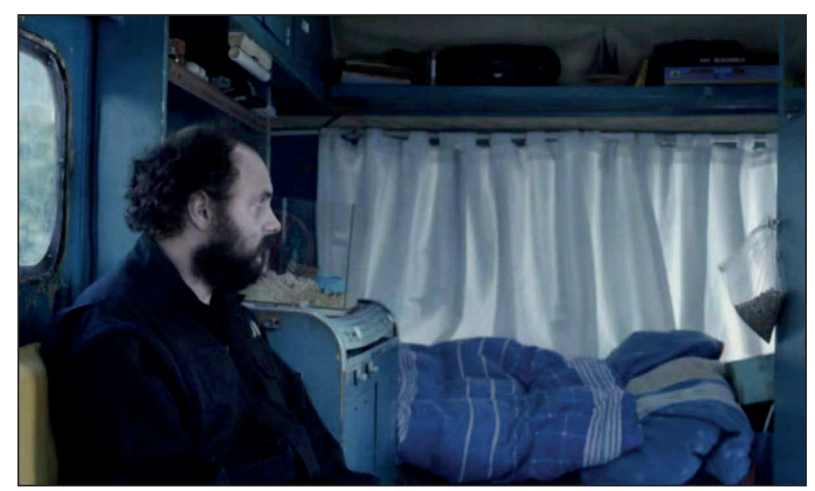

Fot. 16. Muka! (2012, reż. Kordian Kądziela) Arkadiusz Jakubik w roli Józefa - stróża

Życie zawodowe bohatera Muki! przypomina urzędniczą pracę Józefa K. Profesja obu bowiem wydaje się równie pusta i absurdalna. Jest ona rodzajem zajęcia, które wykonuje się codziennie, mrówczą pracą, na którą została skazana jednostka, czy też jednym z aspektów naszej egzystencji, któremu Kafka nadał absurdalny wymiar. W końcu oczekiwanie bohatera zostaje przerwane przez pojawienie się zmiennika. Mężczyzna przekazuje Zydze kurtkę, która jest jedynym elementem służbowego uniformu, zaś Zyga opowiada dowcip, który stanie się analogią życiowej sytuacji bohatera: 
Facet dzwoni do kumpla i mówi: „Stuchaj, może byśmy się spotkali, wypili. Może znowu u ciebie. Ostatnio taka atmosfera była fajna”. No, a ten kumpel mówi: „Wiesz co, my z żona byśmy chcieli, żebyś ty więcej do nas nie przychodzit”. "A co się stało", ten pierwszy mówi. "A wiesz, taka nieprzyjemna sprawa, bo ostatnio jak u nas byłeś, to zginęła nam stówka, no sto złotych". Ten mówi: "No co ty, chyba mnie nie podejrzewasz?". Odpowiada: „Nie, nie, sprawa się wyjaśniła, stówka się znalazła, ale mimo wszystko jednak niesmak pozostał"7.

Losy bohatera Muki! potoczą się w podobny sposób, jak perypetie niesłusznie oskarżonego o kradzież bohatera dowcipu. Po zakończeniu nocnej zmiany mężczyzna wraca do domu. Automatycznie wykonuje wyuczone czynności. Ta codzienna rutyna przywodzi na myśl machinalne czynności Józefa K.: codzienne wyprawy do pracy, odwiedziny przyjaciółki. Bohaterowie Kordiana Kądzieli i Franza Kafki do momentu postawienia w stan oskarżenia zdają się żyć w taki sam bezrefleksyjny, niemalże instynktowny, sposób. Filmowy Józef beznamiętnie wykonuje codzienne obowiązki. Zatrzymuje się na przejściu dla pieszych, by, choć ulica jest całkowicie pusta i z żadnej strony nie nadjeżdżają pojazdy, poczekać na zielone światło i przejść na drugą stronę. Wchodzi po schodach i puka do mieszkania, w którym żyje wraz z matką. Od niej dowiadujemy się, że to rytualne dobijanie się do drzwi też powtarza się codziennie, od czasu gdy, pół roku temu jej syn zgubił klucze. Wraz z Józefem i jego matką znajdujemy się w jego pokoju, który za sprawą wąskiego kadru i sinoniebieskiej kolorystki jest tak samo ciasny i klaustrofobiczny, jak przyczepa - miejsce pracy. Dopełnieniem tej monotonii jest rozkładana przez bohatera meblościanka.

Relacje Józefa z matką przypominają te, które łączą bohatera z Zygą - słucha jej i przytakuje bez zainteresowania. Bohater filmu jest przeraźliwie samotny, nie ma kolegów ani kobiety, jego jedynym przyjacielem jest zamknięty w szklanym terrarium chomik Marcin. Zwierzątko i jego los są też analogią do losów Józefa. Matka opowiada bohaterowi o bezskutecznej próbie ucieczki małego pupila, którą udało jej się udaremnić. Historię kończy stwierdzeniem zaadresowanym do syna: Wariat szalony. Zupetnie jak ty. Porównanie to nie wydaje się bezpodstawne. Kolorystyka i sposób kadrowania otoczenia Józefa przywodzą na myśl ciasne, szklane pudełko, zaś codzienna rutyna przypomina czynności życiowe zamkniętego zwierzęcia. Monotonny los bohatera filmu zostaje zakłócony przez przyjście dwójki ludzi. Józef, podobnie jak protagonista Procesu, zostaje aresztowany. Zarzuty nie zostają mu przedstawione nawet podczas przesłuchania. Śledczy naciskają jedynie, by przyznał się do winy, zaś przesłuchiwany zapewnia, że chciałby pomóc, ale nie wie jak. Na zakończenie

7 Wszystkie cytaty z filmów na podstawie ich list dialogowych. 
pierwszego przesłuchania, tak jak w powieści Kafki, Józef zostaje tymczasowo zwolniony i wraca na nocną zmianę do swojej pracy. Zyga nie ma ochoty już z nim żartować. Jego zmiennik został przecież oskarżony, co utożsamiane jest $\mathrm{z}$ winą.

Perypetie filmowego bohatera początkowo przebiegają podobnie do losów literackiego protagonisty. Reżyser przenosi akcję Procesu w czasy nam współczesne, co można tłumaczyć uniwersalnością postaci Józefa i przesłania Kafki. W dalszej części Muki! losy Józefa przebiegają jednak nieco inaczej. W nocy do jego przyczepy przybywa bowiem jeden ze śledczych, by wyjaśnić, że zaszła pomyłka - chochlik się wkradt - zaś Józef okazał się niewinny. Powinien był, co prawda, od razu uprzedzić o tym śledczych, co zaoszczędziłoby wszystkim sporo czasu, nie mógł jednak tego wiedzieć, gdyż został oskarżony po raz pierwszy w życiu. Nazajutrz, gdy w przyczepie pojawia się zmiennik Zyga, Józef opowiada mu swoją niezwykłą historię bezpodstawnego aresztowania i oskarżenia. Kolega jednak nie zachowuje się jak co dzień, nie zagaduje, nie żartuje. Dzieje się tak, jak w opowiedzianym wcześniej dowcipie: choć wszystko się wyjaśniło i nie udowodniono winy, ,niesmak pozostał”. Podobnie reaguje matka, zaś jej przyjaciel namawia Józefa, by przyniósł zaświadczenie udowadniające jego niewinność, podsumowując wątpliwości matki stwierdzeniem: A jak ma ci uwierzyć. Wczoraj taki cyrk, a dziś przychodzi, jakby nigdy nic. Aresztowanie i oskarżenie staje się dla Józefa rodzajem piętna, które wyklucza go ze społeczności.

Józef wyrusza po zaświadczenie, ale sprawa okazuje się nie taka prosta. Nie może nigdzie odnaleźć śledczych, zaś portier z sądowego budynku informuje, że nie mamy orzeczeń o niewinności, o winie owszem, od tego tu jesteśmy. Zrezygnowany Józef wraca do matki. Ta jednak już zdążyła wystawić rzeczy syna przed drzwi mieszkania i nie reaguje na jego łomotanie do drzwi. Zrezygnowany syn zabiera swoje manatki, w tym także terrarium z chomikiem Marcinem. Od tej pory mieszka w przyczepie - swoim miejscu pracy. Po zakończonej zmianie, $\mathrm{z}$ trudem krząta się w swoim nowym ciasnym mieszkaniu. Zyga, podobnie jak matka, ignoruje go. W końcowej scenie Józef karmi Marcina, a następnie kładzie się na swoim materacu i zasypia.

Etiuda Kordiana Kądzieli to bardzo ciekawa i konsekwentna adaptacja Procesu. Autor filmu zmienia fabułę literackiego pierwowzoru i jego zakończenie - Józef jest uniewinniony, zaś w finałowej scenie nie zostaje zamordowany. Warto jednak zauważyć, że takie przedstawienie losów bohatera Procesu nie zmienia w żaden sposób jego położenia. Autor filmu nie tylko zachowuje kafkowski klimat, lecz także zwraca uwagę na fakt, iż Józef zostaje skazany na swój los już na samym początku. Podobnie jak 
w literackim oryginale, w momencie zawiązania akcji znamy już jej zakończenie. Wina nie potrzebuje bowiem dowodu, zaś swojej niewinności nie sposób dowieść ani u Kafki, ani u Kądzieli. Dramat filmowego bohatera potęguje brutalnie ironia, z jaką opisane są jego losy. Egzystencja Józefa przypomina losy bohaterów niewyszukanego dowcipu albo żałosne próby walki z przeznaczeniem podejmowane przez chomika. Absurd losu Józefa wyraża także tytuł filmu. Jego oskarżenie jest jak muka - w slangu młodzieżowym niezasłużony kuksaniec na ulicy - który boli tylko poszkodowanego, zaś dla postronnych obserwatorów staje się przyczynkiem do drwin. Reżyserowi filmu udaje się także uchwycić samotność kafkowskiego bohatera. Otaczający ludzie nie żywią dla niego żadnego współczucia, nie potrafią ani nawet nie starają się zrozumieć dramatu Józefa.

Bohater Muki! nie umiera w finałowej scenie, w istocie jednak kończy jak K., który kres swojej egzystencji kwituje słowami: Jak pies! Zostaje uprzedmiotowiony, potraktowany jak zwierzę, przyrównany do swojego chomika, gdyż, podobnie jak on, nie ma wpływu na swój los. Zostaje zamknięty i uwięziony w swojej egzystencji, skazany na absurd i porażkę. Jego jedynym zajęciem jest bezmyślne gapienie się $\mathrm{w}$ telewizyjny ekran lub w szklane terrarium. Za sprawą zdjęć, ich sinoniebieskiej kolorystyki i kompozycji kadru, sam wydaje się zamknięty w szklanym pudełku. Reżyser, nakazując widzom obserwowanie Józefa, uwięzionej i skazanej na porażkę istoty, uzmysławia nam, że zachowujemy się jak bohater filmu - śledzimy beznamiętnie ludzki los zamknięty po drugiej stronie ekranu. Kordianowi Kądzieli udaje się tym samym uchwycić uniwersalny charakter kafkowskiego przesłania. Józef nie jest nieudacznikiem z fikcyjnej opowieści, ale jednym z nas, któremu przytrafiła się muka - niezasłużony, bolesny kuksaniec od losu, a w szerszym kontekście pozbawiona sensu egzystencja w świecie przepełnionym absurdem.

\section{Defekt, czyli kobieta}

Adaptacja Procesu Małgorzaty Suwały nosi tytuł Defekt i jest komentarzem do szóstego rozdziału powieści - Wuj - Leni. Proza Kafki zostaje odczytana poprzez pryzmat tego fragmentu oraz postaci Leni. Rozdział dotyczy spotkania Józefa z wujem Albertem, który prowadzi go do znajomego sędziego, aby ten pomógł w procesie. $W$ czasie pobytu u sędziego Józef poznaje jego pielęgniarkę, Leni, i wdaje się z nią w romans. To właśnie fragmenty dotyczące Leni stanowią punkt wyjścia do twórczych 
poszukiwań Małgorzaty Suwały oraz jej klucz do adaptacji Procesu. Cechą charakterystyczną Leni jest błona wyrastająca między palcami jednej ręki, którą bohaterka określa mianem „usterki”, zaś autorka filmu „defektem”. Ta drobna niedoskonałość czyni Leni inną od pozostałych kobiet. Wyróżnia ją i zarazem stygmatyzuje. Sprawia, że pośród bohaterów Procesu zajmuje wyjątkowe miejsce.

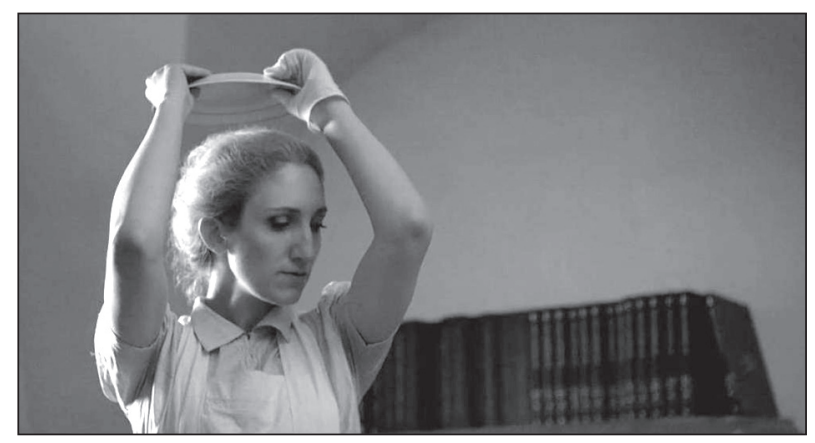

Fot. 17. Defekt (2012, reż. Małgorzata Suwała)

Leni ukrywa swój „defekt” za pomocą rękawiczki

Pozycja Leni jest wyjątkowa. Z jednej bowiem strony, jako pielęgniarka sędziego zajmuje miejsce uprzywilejowane: ma dostęp do poufnych informacji, spotyka sądowych dygnitarzy, wie na temat procesu znacznie więc, niż K. Z drugiej - jest traktowana przedmiotowo przez wuja i K. Ta niejednoznaczna sytuacja Leni stanowi punkt wyjścia dla adaptacji Małgorzaty Suwały. Autorka Defektu czyni z Leni centralną postać swojego filmu. Reżyserka polemizuje z patriarchalnym porządkiem dominującym w Procesie i odczytuje dzieło Kafki z zupełnie innej, kobiecej perspektywy. Opowieść skupia się wokół postaci Leni i przedstawia historię jej emancypacji. Za sprawa poprowadzonej w filmie narracji widzimy w jego bohaterce nie tylko pielęgniarkę sędziego, ale przede wszystkim samotną kobietę, świadomą beznadziejnej sytuacji, w której się znalazła. Pokochała bowiem oskarżonego, a zatem jej miłość skazana jest na niepowodzenie. Jej próby zatrzymania ukochanego Józefa są daremne nie tylko z powodu jego nadmiernego zainteresowania procesem czy też ze względu na fakt posiadania przez niego kochanki Elzy, lecz przede wszystkim dlatego, iż Józef jest oskarżony. Proces Józefa K. to przyczyna dramatu Leni. Absurdalna egzystencja jest także jej udziałem. Wina Józefa wywiera piętno również na życiu Leni.

\footnotetext{
8 Franz Kafka, dz. cyt., s. 75.
} 
Za sprawą Małgorzaty Suwały Leni nabiera podmiotowości. Jej defekt to nie tylko błona pomiędzy palcami, którą zakrywa urastającą do rangi fetysza rękawiczką. Defektem jest także jej beznadziejna miłość do skazańców, gdyż w filmie Suwały sędziego odwiedza nie jeden, lecz wielu K. Multiplikacja postaci Józefa powoduje, że to mężczyzna zostaje sprowadzony do roli fetysza. Każdy z Józefów wywołuje w Leni podobne pragnienie połączone jednocześnie ze świadomością niemożności zaspokojenia go. Pożądanie związane jest nieodzownie z brakiem ukochanego. Dla Leni kochać znaczy tęsknić. Dramat Leni oraz jej uprzedmiotowienie i próby emancypacji doskonale ilustrują kostiumy. Z jednej bowiem strony kobieta ubrana jest w tradycyjny strój pokojówki przywodzący na myśl fetyszystyczne pragnienia, $\mathrm{z}$ drugiej zaś napotyka mężczyzn zunifikowanych, ubranych w takie same garnitury. Postać Leni oscyluje pomiędzy wyuzdaniem a potrzebą miłości do tego jedynego. Wydaje się, że kobieta zmienia, czy też wymienia kochanków, dlatego że zdaje sobie sprawę z ich przemijalności. Są winni, więc odejdą, zaś Leni pozostanie sama.

Defekt otwiera scena rozmowy Leni z jednym z Józefów. Kobieta domaga się uwagi. Najpierw mówi do ukochanego, że chciałaby z nim porozmawiać. Za chwilę przemawia $w$ jego imieniu, zgodnie $\mathrm{z}$ własnym wyobrażeniem idealnej miłości: Chciałbym z toba porozmawiać. W kolejnych scenach dialogi, które w Procesie były nawiązywane pomiędzy Leni a Józefem, wypowiadane są przez jedną kobietę i różnych mężczyzn. Aktorzy grający postać K. występują w różnych ujęciach tych samych scen. Leni siada na kolanach jednego ukochanego, by za chwilę spojrzeć w oczy komuś innemu. Jej zachowanie wydaje się jednak nie oznaką wyuzdania, ale potrzeby miłości. W świecie Leni nie sposób bowiem kochać jednego mężczyzny, skoro każdy $\mathrm{z}$ nich po kolei odchodzi. Potwierdzeniem tej tezy zdaje się następna scena, w której Leni z wysoko podwiniętą spódnicą i odsłoniętymi udami siedzi na kolanach sędziego, ten zaś napomina ją: Przygotuj się, zaraz przyjdzie kolejny petent. Wuj Albert i jeden z Józefów pojawiają się ponownie, zaś Leni, po opuszczeniu pokoju sędziego wykonuje gest opisany także przez Kafkę - rozbija talerz. Czynność ta, w Procesie pojawiająca się tylko raz i mająca na celu zwabienie Józefa za sprawą tłuczonego szkła, w Defekcie urasta do rangi rytuału. Talerz rzucony na podłogę jest jak magiczne zaklęcie, dzięki któremu kolejny skazaniec przyjdzie do Leni i weźmie ją w swoje ramiona.

Fragmenty Procesu, które w powieści Kafki wydają się przejawami kokieterii Leni, zyskują w Defekcie zupełnie inne, nowe znaczenie. Kobieta stwierdzająca, że nie chce rozmawiać w kółko o procesie, albo dopytująca się o kochankę Elizę i komentująca jej zdjęcie: Brzydka jest, w ujęciu Suwały wydaje się nie flirtującą pokojówka, lecz osobą, która mówi ukochanemu 
wyświechtane frazesy, by nadać pozory normalności swojej relacji. Stara się skupić uwagę nie na sprawach służbowych; ukazuje swoją zazdrość o kochankę K., by przyciągnąć do siebie uwagę ukochanego. Na pożegnanie zaś rzuca mu klucz i mówi: Teraz należysz tylko do mnie, co w kontekście procesu i czekającej Józefa kary śmierci, z egoistycznego frazesu wyuzdanej pokojówki staje się wołaniem o miłość w świecie nieczułym na ludzkie cierpienie. W oczach sędziego i Alberta Leni wydaje się wesoła albo bardzo dobrze udaje smutek; z perspektywy widza i scen, w których kobieta w samotności oczekuje K., bohaterka Defektu zdaje się postacią smutną, która udaje wesołość, by sprostać oczekiwaniom mężczyzn wobec etosu frywolnej pokojówki. Diagnoza otaczających Leni mężczyzn jest zupełnie inna od tej postawionej przez Małgorzatę Suwałę.

Finał Defektu pod względem fabularnym nie różni się od końcowej sceny Procesu. Józef zostaje zamordowany. Na śmierć prowadzi go dwóch mężczyzn. Widzowie filmu Małgorzaty Suwały wiedzą jednak, że ci mężczyźni to także oskarżeni K. Scenie przygląda się ze wzniesienia Leni. $Z$ jej punktu widzenia nie ma różnicy, kto zamordował, kto zaś był ofiarą. Ważne, że wszyscy ukochani odeszli. Podobnie jak dla otaczających ją mężczyzn - skazańców i skazujących, tak dla niej dotychczasowe życie było także absurdalnym dramatem. Jednakże, w momencie ich odejścia, Leni staje się wolna od miłości do nich, od tęsknoty, a zatem i od cierpienia. Jej los został spleciony z ich losem. W finałowej scenie najpierw tęsknym i pełnym cierpienia wzrokiem śledzi trójkę Józefów, skazanych na to, by umierać lub wykonywać wyrok, następnie zaś odwraca się na pięcie i kroczy poprzez łąkę. Idzie sama, lecz już nie samotnie. Towarzyszy jej utwór muzyczny o wymownym tytule Walk on by, czyli „idź swoją drogą". Leni straciła ukochanego. Dom, w którym pełniła funkcję pokojówki, pozostawia za sobą. Nie towarzyszy jej również żaden z Józefów, którzy w romansie $z$ Leni upatrywali swoich szans na wygranie procesu. Kobieta kroczy poprzez łąki i choć mogłoby się wydawać, że zostawiła wszystko, w interpretacji Małgorzaty Suwały zyskuje własną podmiotowość. Kolejny z epizodów jej życia, zamiast odwoływać się do usterki na jej ciele, z pewnością opisywałby jej siłę i zmagania z absurdalnym istnieniem.

\section{Poczekalnia, czyli nadzieja}

Poczekalnia w reżyserii Michała Wawrzeckiego to dzieło inspirowane twórczością Kafki. Etiuda nie jest wiernym odzwierciedleniem powieści. Reżyser traktuje fabułę Procesu w sposób niezwykle swobodny, podejmuje 
jednak kafkowskie tropy: problemy egzystencjalne i filozoficzne związane z samotnością, brakiem zrozumienia i logiki w absurdalnym świecie. Rozwiązanie to, choć może wydawać się kontrowersyjne, jest ciekawe z uwagi na specyfikę literackiego pierwowzoru czy też twórczości Franza Kafki potraktowanej całościowo. Ostatecznie bowiem najistotniejsza wydaje się nie sama akcja powieści i realia, w których została osadzona, lecz podejmowane w niej problemy. Michał Wawrzecki zdaje się odczytywać twórczość Kafki w duchu filozofii Sørena Kierkegaarda, dla którego jednym z najważniejszych aspektów ludzkiej egzystencji było przeciwieństwo jednostki i otaczającego ją świata pojętego jako paradoks, rozumiany jako kategoria i określenie estetyczne ${ }^{9}$. Warto także zauważyć, że reżyser zachowuje strukturę fabularną Procesu, chociaż umieszcza akcję swojej etiudy w całkowicie innych realiach. Wydarzenia rozgrywają się bowiem nie w budynkach sądów, urzędów czy katedr, ale na dworcu kolejowym. Takie umiejscowienie akcji zwraca uwagę na uniwersalność kafkowskiego przesłania, a także problematyczność adaptacji Procesu, związaną z faktem, że moment zawiązania akcji jest właściwie jej rozwiązaniem. Nie ma bowiem sposobu, by uniknąć oskarżenia. Już samo istnienie we wrogim świecie tożsame jest ze zmaganiem się z rządzącymi w nim absurdalnymi prawami. Bohater Poczekalni, podobnie do Józefa K., do końca nie traci jednak nadziei, stara się walczyć i wierzyć, że jego przygoda może mieć pozytywne - czy też po prostu racjonalne - zakończenie.

Poczekalnia jest opowieścią o dojrzewaniu do absurdu, historią uzmysławiania sobie sensu, czy też raczej bezsensu ludzkiej egzystencji. Wolność i samoświadomość okazują się jedynie ułudą, rodzajem pocieszającej fikcji, w którą wierzymy, ponieważ boimy się dostrzec, że ludzki los jest zdeterminowany $\mathrm{w}$ sposób wymykający się zdroworozsądkowemu poznaniu. Nasz „swojski, dobrze znany, uporządkowany świat z jego prawami przyrody, zasadami moralnymi, hierarchiami społecznymi itd. jest tylko maską, pod którą kryje się zupełnie inna rzeczywistość. Światem $\mathrm{w}$ istocie rządzą jakieś tajemnicze, anonimowe siły, kierujące się prawami, których nie potrafimy zrozumieć" ${ }^{\prime 10}$. Etiuda Michała Wawrzeckiego wydaje się opowieścią o odkrywaniu tej przerażającej zasady kierującej światem.

Otwierająca film scena przedstawia biegnącego przez łąki bohatera, który dociera do skrzyżowania trzech dróg, wybiera jedną z nich i dociera do małej stacji kolejowej. Sekwencja ta zdaje się nawiązywać i polemizować z Przypadkiem Krzysztofa Kieślowskiego (1981). Jednak, w odróżnieniu od

9 Karol Toeplitz, Kierkegaard, Wiedza Powszechna, Warszawa 1980, s. 154.

10 Leszek Kleszcz, Pochwała absurdu, [w:] Absurd w filozofii i literaturze, red. Ryszard Różanowski, Wyd. Uniwersytetu Wrocławskiego, Wrocław 1998, s., 14. 
Witka Długosza, wybory bohatera Warzechy sprawiają wrażenie pozornych. Istotą tragizmu kafkowskiego bohatera jest bowiem jego absurdalny los, w obrębie którego nie ma możliwości wyboru. Wszystkie alternatywy dotyczą bowiem tego samego, pozbawionego racjonalności świata i już sam fakt egzystencji, bycia w świecie, skazuje nas na absurd. Bohater Poczekalni dociera na dworzec, by kontynuować swoją podróż koleją, w kasie biletowej dowiaduje się jednak, że przyszedł za późno. Postępując zgodnie z zasadami zdroworozsądkowej logiki, usiłuje zakupić bilet na inny pociąg. Próby te okazują się jednak daremne. Sprzedający bilety zamyka kasę, zaś rozkład jazdy okazuje się nieczytelny.

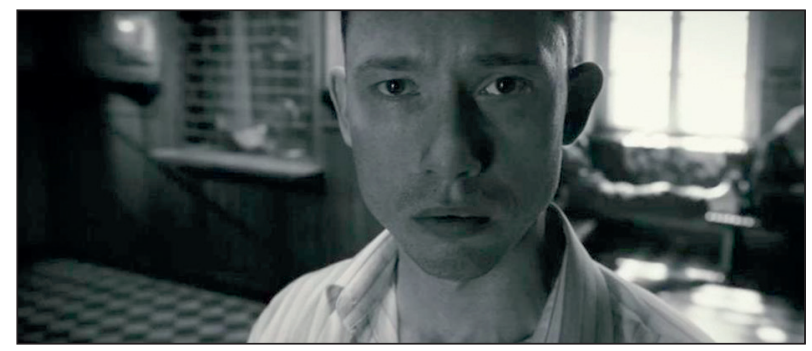

Fot. 18. Poczekalnia (2012, reż. Michał Wawrzecki) Bohater czeka na dworcu, z którego nie odjeżdżają żadne pociągi

Bohater zostaje na dworcu. Czeka. Jego sytuacja jest analogiczna do tej, w której znalazł się Józef K., gdy pewnego poranka pojawili się u niego śledczy. W przeciwieństwie jednak do Józefa, bohater Poczekalni może wydostać się ze swojej opresyjnej sytuacji, powracając na rozstaje dróg i wybierając inną z nich. Pozostaje jednak na dworcu, gdyż ma jeszcze nadzieję, że upragniony pociąg nadjedzie i on sam będzie kontynuował podróż. Determinują go zatem nie tylko siły zewnętrzne, ale jego własne przekonania skłaniające go do interpretacji świata zgodnie z prawami logiki i zdrowego rozsądku. Dopiero w ostatniej scenie filmu, rozgrywającej się na opustoszałym peronie, dowiemy się, że na dworcu od dawna nie kursują żadne pociągi. Zasugeruje to dobitnie obraz trawy porastającej tory oraz długi rząd monet ustawionych na szynach po to, by zgodnie z zasadami dziecięcej zabawy przejechał po nich pociąg. Scena ta, choć na próżno szukać jej w prozie Kafki, jest jednak na wskroś nasycona duchem jego powieści. Jest bowiem świadectwem nadziei bohaterów, którzy, na przekór niezrozumiałym okolicznościom, do końca wierzą, że ich zdroworozsądkowy plan się powiedzie. Ilość ułożonych monet świadczy o tym, że bohater 
Poczekalni nie jest osamotniony w swoim oczekiwaniu na pociąg. Podobną nadzieję żywiło wielu jego poprzedników. Jednostkowe przeżycia bohatera zyskują wymiar uniwersalny, wpisany w świat diegetyczny. Musiał mierzyć się z absurdem samotnie, jednakże jego indywidualne zmagania nie są jednostkowe, lecz wpisane w egzystencję każdej jednostki.

Uniwersalność tragicznego losu jednostki nie umożliwia nawiązania kontaktu $\mathrm{z}$ innymi ludźmi wrzuconymi w istnienie. Bohater rozgląda się po ciasnej przestrzeni dworca, w której napotyka innych podróżnych oraz pracowników. Wszyscy oni pogrążeni są w marazmie, tylko niektórzy z nich wydają się zainteresowani pojawieniem się nowego przybysza. Bohater nie potrafi jednak nawiązać z nimi kontaktu, jest osamotniony w swoim beznadziejnym oczekiwaniu na pociąg. Samotność, problem z komunikacją i brakiem zrozumienia ze strony innych ludzi charakteryzuje nie tylko Józefa K., lecz wszystkich kafkowskich bohaterów. Reżyser Poczekalni, odstępując od zamiaru wiernej adaptacji Procesu, zdaje się poszukiwać inspiracji także w innych powieściach Kafki. Losy filmowego bohatera, który domaga się biletu, by udać się do pracy, przywodzą na myśl przede wszystkim Zamek i jego bohatera - geometrę K., który na próżno usiłuje się do niego dostać, by wywiązać się z zadania. Odstępując od literackiego pierwowzoru i umieszczając swojego bohatera w scenerii niemającej związku z Procesem, reżyser filmu zwraca uwagę na egzystencjalny i ontyczny aspekt sytuacji, w których znajdują się Kafkowscy bohaterowie. Tytułując etiudę Poczekalnia, nie zaś Dworzec, Michał Wawrzecki podkreśla paradoksalność kafkowskiego oczekiwania, które nie tylko zawsze kończy się fiaskiem, lecz także od początku wydaje się pozbawione sensu. Bohatera filmu i Procesu łączy poczucie absurdu rodzącego się

w zderzeniu jednostki, jej życia, prywatnego świata w miarę uregulowanego i subiektywnie odczuwanego jako normalny oraz sensowny, z sytuacją społeczną machiną której nieprzeniknione tryby pozbawione są jakichkolwiek związków logicznych i deterministycznych. Nie dająca się zrozumieć rzeczywistość ujawnia tylko swą moc negatywna, niszczy jednostkę, powoduje rozpad subiektywnej struktury sensu, uniemożliwia komunikację ${ }^{11}$.

Michał Wawrzecki, choć nie dokonuje wiernej adaptacji powieści, podąża tym samym tropem co Kafka, który

11 Ryszard Różanowski, Absurd nasz powszedni, [w:] Absurd w filozofii..., s. 45. 
chce wyrazić absurd, jego metodą jest koherencja. Znana jest historia o wariacie, który łowił ryby w wannie; lekarz, psychiatra niebanalny, pyta go, czy „ryba bierze”. „Nie, durniu - odpowiada surowo wariat - przecież to wanna". Jest to historyjka z rodzaju dziwacznych, ale pokazuje jasno, jak ściśle efekt absurdalny wiąże się z nadmiarem logiki. Niesłychany świat Kafki to w gruncie rzeczy świat taki, gdzie człowiek pozwala sobie na zabójczy luksus łowienia ryb w wannie wiedząc, że nic z tej wanny nie wyłowi ${ }^{12}$.

Bohater Poczekalni czeka na pociąg, pomimo zapewnień towarzyszy, że ten nigdy nie nadjedzie. Nawet widok porośniętych trawą torów nie jest w stanie skłonić go do zmiany swojego postanowienia. Nie opuszcza dworca, by szukać innego środka transportu. Jego podróż, będąca doskonałą metaforą życia, nie jest kontynuowana dlatego, że wciąż żywi nadzieję, iż świat opiera się na prawach podyktowanych przez zdrowy rozsądek.

\section{Proces jako metafora}

Analizowane przeze mnie etiudy studenckie nie są wiernym przeniesieniem fabuły powieści Kafki na język filmu. Sądzę jednak, że w przypadku Procesu taka swobodna interpretacja literackiego pierwowzoru jest jednak w pełni uzasadniona i wynika nie tyle $\mathrm{z}$ braku umiejętności czy też reżyserskiego kunsztu, lecz jest zabiegiem celowym, odwołującym się do figury metafory rozumianej za Ricoeurem jako trop stylistyczny, który „mówi nam coś nowego o rzeczywistości”13. Indywidualne i odkrywcze odczytanie powieści przez młodych reżyserów jest nie tylko ciekawym zabiegiem artystycznym, lecz także wydaje się pewną konsekwencją wynikającą z Kafkowskiego pisarstwa. Proces jest bowiem powieścią-zagadka, która wymaga od czytelnika rozwiązania, a przede wszystkim refleksji nad własną sytuacją egzystencjalną i statusem w świecie. Podobny, paraboliczny sens zachowują również studenckie próby adaptacji utworu Kafki. Zrywając z wiernym przedstawieniem powieści, zwracają naszą uwagę na jej wyselekcjonowane elementy, motywy, postaci i podejmowane problemy, by stwierdzić coś nowego nie tylko o Procesie, lecz przede wszystkim o ludzkiej kondycji, samotności i nieprzystawalności subiektywnej wizji świata do rządzących nim praw.

12 Albert Camus, dz. cyt., s. 191.

13 Paul Ricoeur, Jezyk, tekst, interpretacja, tłum. Piotr Graff, Katarzyna Rosner, PIW, Warszawa 1989, s. 130. 